\title{
ODC1 Gene
}

National Cancer Institute

\section{Source}

National Cancer Institute. ODC1 Gene. NCI Thesaurus. Code C38930.

This gene plays a role in ornithine metabolism. 